\title{
SPERMATOGENESIS IN MATURE AND REGRESSED TESTES OF THE VOLE (MICROTUS AGRESTIS)
}

\author{
C. ANNE GROCOGK* AND J. R. GLARKE \\ Department of Agricultural Science, University of Oxford, \\ Parks Road, Oxford OX1 $3 P F$
}

\section{(Received 25th October 1974)}

\begin{abstract}
Summary. Eight stages of spermatogenesis, each with a characteristic frequency and germ cell association could be recognized in the vole. There was no difference between laboratory bred and field animals in the frequency of the stages. Counts of the different types of germ cell showed that there was considerable cell loss during spermatogonial mitotic and spermatocytic meiotic divisions. Only $60 \%$ of germ cells became spermatozoa in sexually mature animals, and $19 \%$ in the regressing testes of voles exposed to short photoperiods. Animals with regressed testes probably have lowered circulating levels of gonadotrophins and testicular hormones, so that the greater germ loss suggests the importance of these hormones in the regulation of germ cell wastage. From the cell counts in mature animals, a scheme of cell divisions has been suggested by which spermatogonia produce progressively more highly differentiated germ cells while continuing to perpetuate stem cells.
\end{abstract}

\section{INTRODUCTION}

Studies of seasonal breeding in the vole (Baker \& Ranson, 1933; Clarke \& Forsyth, 1964) and of the rôle of photoperiod in its causation (Baker \& Ranson, 1932; Clarke \& Kennedy, 1967; Grocock \& Clarke, 1974), have uncovered basic problems of spermatogenesis. Under field conditions, testes are fully functional during the spring and summer but produce few or no spermatozoa during the winter. Such differences in activity can be brought about in the laboratory by exposing voles to long photoperiods (such as $16 \mathrm{hr}$ light and $8 \mathrm{hr}$ dark/day) which allow complete spermatogenesis, or short photoperiods ( $<12 \mathrm{hr}$ light/day) in which testicular development will be inhibited, or initially mature testes will regress. In such inhibited or regressed testes, spermatogenesis is often incomplete (Clarke \& Kennedy, 1967; Grocock \& Clarke, 1974). As a first step towards establishing where and how spermatogenesis fails when voles are exposed to short photoperiods, we have investigated its stages and counted the different types of germ cell. This has enabled us to estimate germ cell loss at different phases of the process, and to outline a tentative scheme for cell divisions in vole spermatogenesis.

* Present address: Department of Human Anatomy, University of Oxford. 


\section{MATERIALS AND METHODS}

The fourteen mature males whose testes were taken as representative of complete spermatogenesis comprised eight animals $2 \frac{1}{2}$ to $3 \frac{1}{2}$ months old, derived from the laboratory stock (a closed colony since 1958), and six trapped alive in the field in June by the method of Chitty \& Kempson (1949). Thirteen other laboratory stock males, which had been reared on the standard laboratory photoperiod of $16 \mathrm{hr}$ light/day, were transferred when sexually mature to a short photoperiod ( $7 \mathrm{hr} 15 \mathrm{~min}$ light/day) for 3 months. Testes from six of these animals were selected for the detailed study of epithelial regression. In the remaining seven animals, regression was so extensive that the identification of the eight stages of spermatogenesis was impossible. Testes of sexually mature laboratory and field animals were fixed in Zenker's fluid, and the regressed testes in Bouin's fluid. All testes were embedded in paraffin wax, sectioned at $5 \mu \mathrm{m}$ and stained with Periodic acid-Schiff reagent and Harris's haematoxylin, or with Ehrlich's haematoxylin and eosin. The different cell types which occur during spermatogenesis are similar to those described for other species (see Ortavant, Courot \& Hochereau, 1969). An unusual, prominent, round chromatin body occurs in nuclei which is most conspicuous in primary spermatocytes during pachytene (see, for example, Pl. 1, Fig. 3). To establish the frequency of each of the eight stages of spermatogenesis (Roosen-Runge \& Giesel, 1950; Ortavant, 1958; Swierstra \& Foote, 1963; Swierstra, Gebauer \& Pickett, 1974), fifty seminiferous tubules in two locations at least $300 \mu \mathrm{m}$ apart in each testis were classified, making a total of 1600 tubules in the mature laboratory voles and 1200 in the mature field animals. Cell loss during spermatogenesis in mature and regressed testes was determined for each animal from counts of all germ types in four cross-sections of seminiferous tubules representative of each of the eight stages of spermatogenesis. Nuclear diameter was measured for five cells of each type in each tubule. All cell counts were corrected to true counts using an adaptation of Abercrombie's formula (Swierstra \& Foote, 1963):

$$
\mathrm{P}=\mathrm{C} \cdot \frac{\mathrm{T}}{\mathrm{L}+\mathrm{T}} \cdot \frac{\mathrm{D}^{1}}{\mathrm{D}}
$$

where $\mathbf{P}=$ average number of nuclear points per cross-section, $\mathrm{C}=$ crude count of the number of whole and cut nuclei in the cross-section, $\mathrm{T}=$ section thickness in $\mu \mathrm{m}, \mathrm{L}=$ diameter of nuclei in $\mu \mathrm{m}, \mathrm{D}=$ diameter in $\mu \mathrm{m}$ of each particular seminiferous tubule, $\mathrm{D}^{1}=$ the mean diameter of 224 mature or 192 regressed tubules (183 $\mu \mathrm{m}$ and $168 \mu \mathrm{m}$, respectively).

\section{RESULTS}

The weights of the testes and seminal vesicles are given in Table 1.

\section{Composition and frequency of stages of spermatogenesis}

The eight stages of spermatogenesis recognized were as follows (Pl. 1, Figs 1 to 4 ; Pl. 2, Figs 5 to 8 ). Stage I. Spermatids were identified with round nuclei but none with elongated ones. Type ' $A$ ' spermatogonia, early leptotene and 
pachytene primary spermatocytes also occurred. Stage II. This was characterized by the elongation of the spermatid nuclei. Type ' $\mathrm{A}$ ' spermatogonia, leptotene and pachytene primary spermatocytes were also present. Stage III. Spermatids were identified with elongated nuclei but none with round ones. 'Type ' $A$ ' spermatogonia, leptotene and late pachytene primary spermatocytes were also found. A prominent round chromatin body was conspicuous in the nuclei of primary spermatocytes during pachytene. Stage IV. During this stage, the first maturation division was completed, and secondary spermatocytes and spermatids with round nuclei were seen. Type ' $A$ ' spermatogonia, zygotene primary spermatocytes and groups of spermatids with elongated nuclei were also present. Stage $V$. Intermediate as well as 'A' spermatogonia, primary spermatocytes between zygotene and pachytene, and spermatids with round or elongated nuclei were recognized, the latter type occurring in groups at Sertoli cells.

Table 1. Weights of mature and regressed testes, and of corresponding seminal vesicles in voles

\begin{tabular}{lccc}
\hline & $\begin{array}{c}\text { No. of } \\
\text { voles }\end{array}$ & Testes* & Seminal vesicles $\dagger$ \\
\hline Mature laboratory & 8 & $431 \cdot 3 \pm 45 \cdot 1$ & $135 \cdot 9 \pm 20 \cdot 8$ \\
Mature field & 6 & $376 \cdot 6 \pm 30 \cdot 1$ & $133 \cdot 1 \pm 14 \cdot 3$ \\
Regressed & 6 & $170 \cdot 3 \pm 21 \cdot 8$ & $76 \cdot 93 \pm 16 \cdot 2$ \\
\hline
\end{tabular}

Weights expressed as Means \pm S.E. in $\mathrm{mg}$.

* Fresh weight.

$\dagger$ Fixed weight.

Stage VI. Intermediate spermatogonia, and the spermatids with elongated nuclei were moving from the Sertoli cells towards the lumen. There were also 'A' spermatogonia, pachytene primary spermatocytes and spermatids with round nuclei. Stage VII. Spermatids with elongated nuclei were beginning to line the tubule lumen. On some of them residual bodies could be seen. At the basement membrane, there were ' $A$ ', intermediate and ' $B$ ' spermatogonia. Pachytene primary spermatocytes and spermatids with round nuclei also occurred. Stage VIII. Spermatozoa were lining the tubule lumen, while, at the basement membrane, there were ' $A$ ' and ' $B$ ' spermatogonia and preleptotene primary spermatocytes. There were also pachytene primary spermatocytes and spermatids with round nuclei.

The frequencies of the stages in laboratory and field animals are shown in Table 2. A $\chi^{2}$ test showed no statistically significant difference between them.

\section{Cell counts for mature and regressed testes}

The numbers of each cell type at the eight stages are shown in Tables 3 and 4, from which Table 5 is derived. When two different generations of primary spermatocytes occurred, they were designated 'young' if in the leptotene or zygotene stages, and 'old' if in pachytene. The numbers for each represented independently all primary spermatocytes. The figure for primary spermatocytes in Table 5 is the mean of all numbers for both young and old primary spermato- 
cytes. Stage IV was omitted from this calculation since maturation division was occurring at this stage, and the numbers of primary spermatocytes, shortlived secondary spermatocytes and round spermatids were therefore unrepresentative of the total yield of these cell types. Likewise, the figures for round spermatids, elongated spermatids and spermatozoa are the means of each relevant row in Tables 3 and 4 . The round spermatids of stage IV were omitted for the reasons given above.

Table 2. Frequencies of stages of spermatogenesis (Mean \pm S.E.) for sexually mature laboratory and field voles

\begin{tabular}{|c|c|c|}
\hline \multirow{2}{*}{$\begin{array}{c}\text { Stage of } \\
\text { spermatogenesis }\end{array}$} & \multicolumn{2}{|c|}{$\%$ Frequency } \\
\hline & Laboratory & Field \\
\hline I & $14.9 \pm 1 \cdot 1$ & $13 \cdot 2 \pm 1 \cdot 1$ \\
\hline II & $12 \cdot 1 \pm 0 \cdot 6$ & $10 \cdot 6 \pm 0.8$ \\
\hline III & $5 \cdot 1 \pm 0 \cdot 4$ & $5 \cdot 2 \mp 0 \cdot 8$ \\
\hline IV & $9 \cdot 5 \pm 0.6$ & $9.2 \pm 0.7$ \\
\hline $\mathrm{V}$ & $7.1 \pm 0.8$ & $9 \cdot 6 \pm 1 \cdot 1$ \\
\hline VI & $12 \cdot 6 \pm 0.8$ & $15 \cdot 2 \pm 0.8$ \\
\hline VII & $15.8 \pm 0.8$ & $12 \cdot 9 \pm 1 \cdot 6$ \\
\hline VIII & $22 \cdot 9 \pm 1 \cdot 6$ & $24 \cdot 1 \pm 1.5$ \\
\hline
\end{tabular}

For mature voles, there are reasons for supposing (see Discussion) that twenty-four ' $B$ ' spermatogonia should arise from a stock of two ' $A$ ' spermatogonia (see stage VIII, Table 3 ). These 'B' spermatogonia would yield fortyeight primary spermatocytes and 192 spermatids and spermatozoa, as shown in Table 5. Accepting this, an $11.3 \%$ deficiency in ' $B$ ' spermatogonia was observed in the mature males $(24-21 \cdot 3 / 24 \times 100)$. Further cell losses occurred at later steps that were not simply a perpetuation of this initial deficiency in ' $B$ ' spermatogonia. It appeared that the ' $B$ ' spermatogonia which did survive multiplied with insignificant cell loss to become primary spermatocytes, but during the ensuing maturation divisions cell loss was greatly increased. The 42.0 primary spermatocytes should produce 168.0 round spermatids in the absence of cell loss specific to these steps in spermatogenesis. The observed yield of 113.8 was $32 \%$ less than this already adjusted figure. No further loss occurred as spermatids matured into spermatozoa, although Table 3 shows a slight reduction in sperm numbers in stages VII and VIII.

\section{EXPLANATION OF PLATES 1 AND 2}

Sections of the testis of voles to illustrate the eight stages of spermatogenesis. The sections, stained with Ehrlich's haematoxylin and eosin, are all at the same magnification. The scale line in Fig. 1 is $20 \mu \mathrm{m}$. Figs 1 to 8 correspond to stages I to VIII. Abbreviations: $\mathrm{s}=$ Sertoli cell nucleus; $\mathrm{A}, \mathrm{In}, \mathrm{B}=\mathrm{A}$, intermediate and $\mathrm{B}$ spermatogonia; prl = preleptotene primary spermatocytes; $1=$ leptotene primary spermatocytes; $p=$ pachytene primary spermatocytes; $\mathbf{2}=$ secondary spermatocytes; $s p d r=$ round spermatids; spde $=$ elongated spermatids; $\mathrm{spz}=$ spermatozoa; $\mathrm{ch}=$ chromatin body; $\mathrm{r}=$ residual body. 

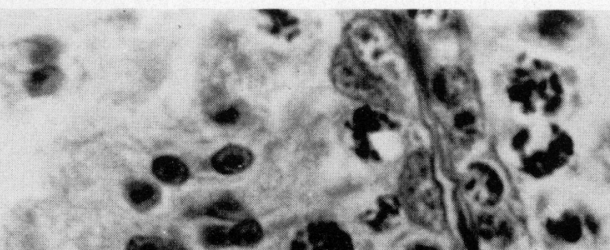

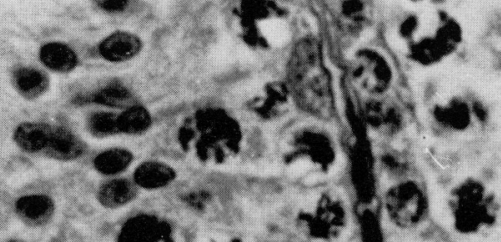

$-3+36$ $-3,515$

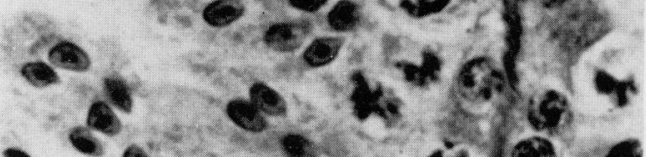

$\because 0^{\circ}+80$ $0.0,960^{\circ}$ $\because \rightarrow x^{3}+x^{2}$ $\rightarrow+4$ $.0 \%$ 0000.

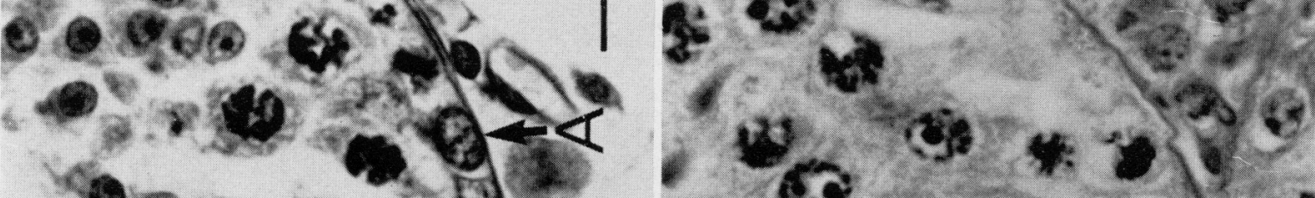
- -120

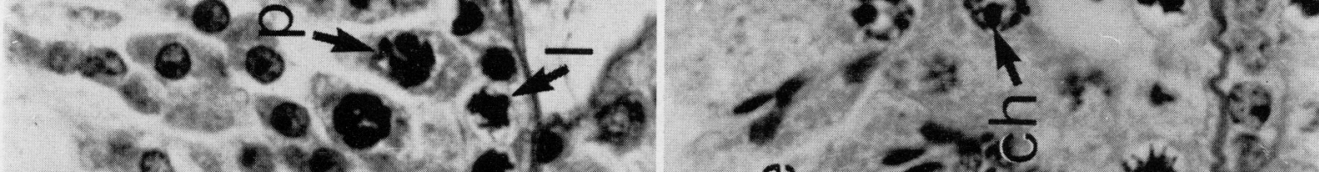
tes ces

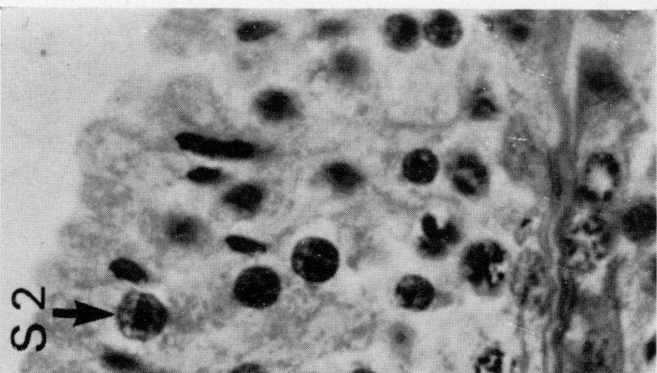

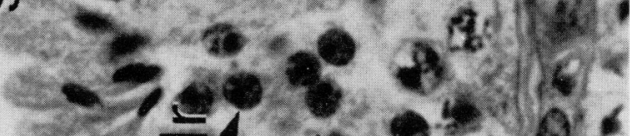

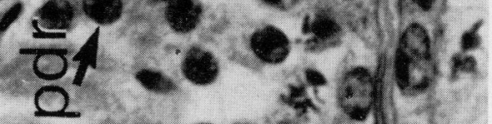

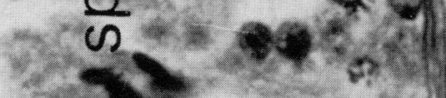

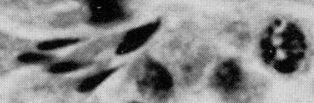

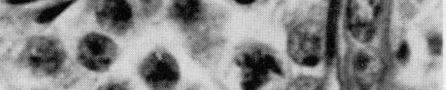
(1)

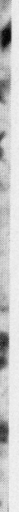


PLATE 2

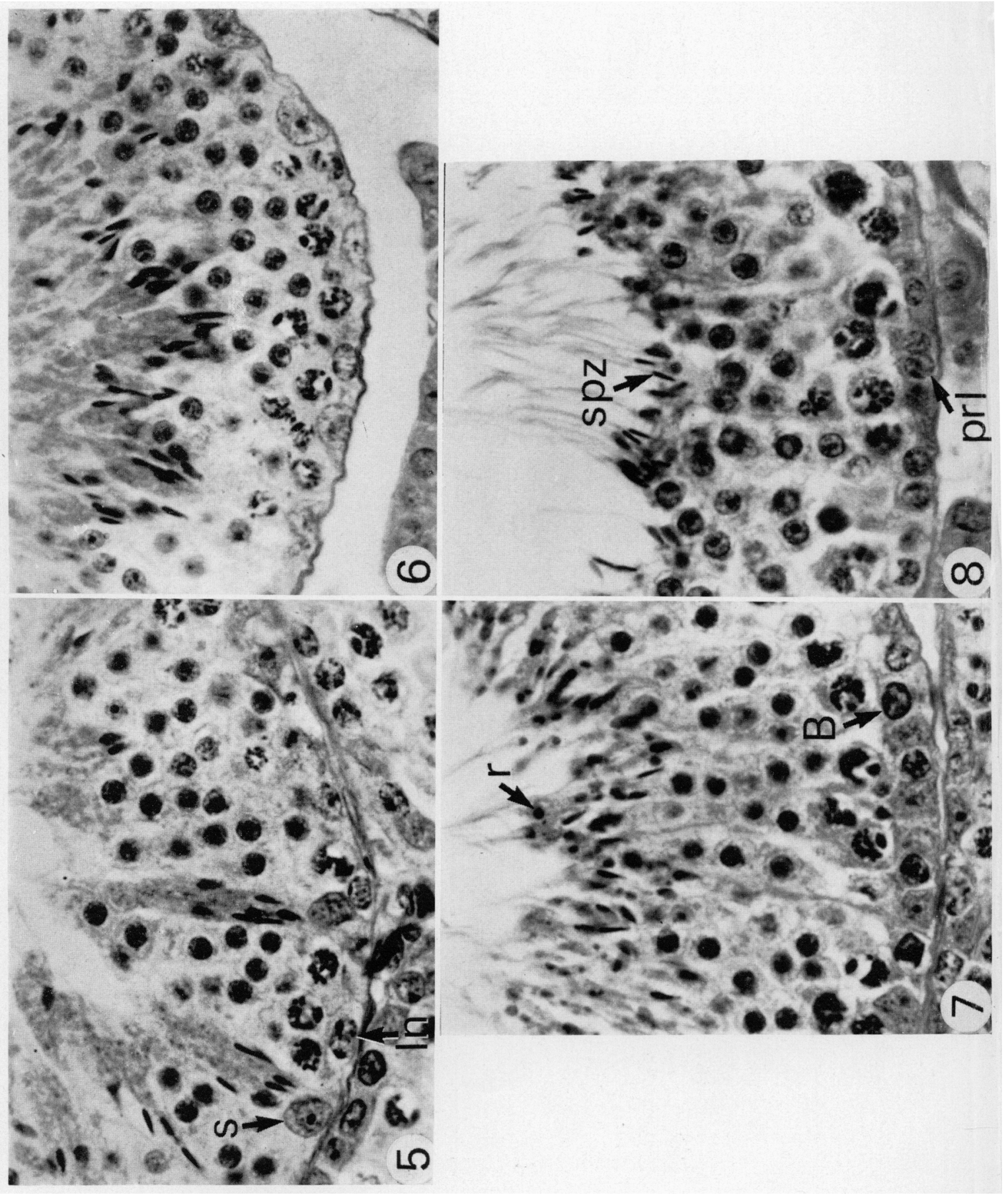




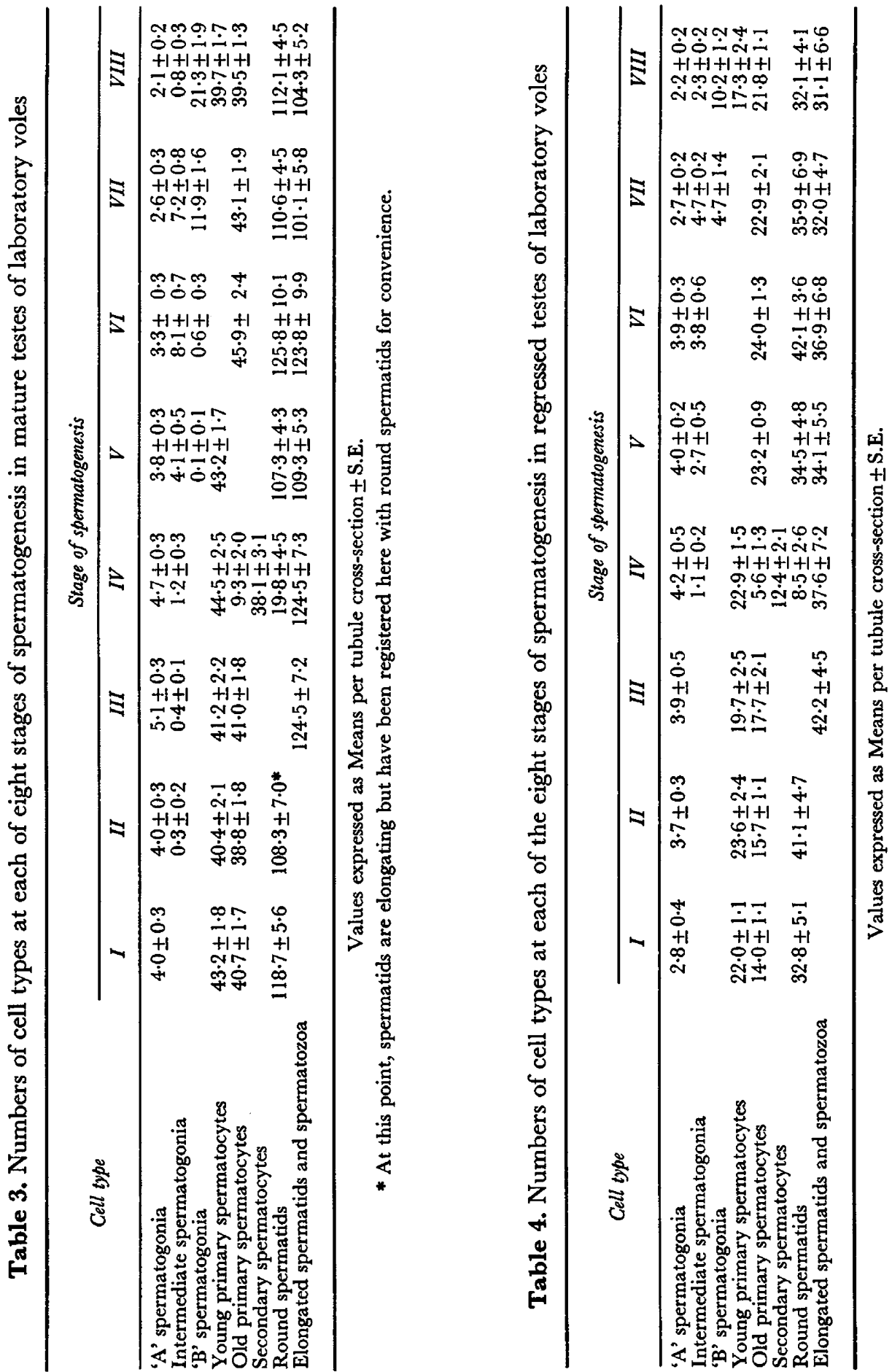


Compared with mature testes, the regressed ones had fewer intermediate and ' $B$ ' spermatogonia (Tables 3, 4 and 5). Such ' $B$ ' spermatogonia as there were multiplied without loss to become primary spermatocytes. The 20.7 primary spermatocytes should have yielded 82.8 round spermatids, if there had been no cell loss at these maturation divisions. Instead, only 36.4 round spermatids were formed. No further cell loss took place as the spermatids transformed into spermatozoa. Over-all, only $60 \%$ of germ cells in mature, and $19 \%$ in regressed, testes became spermatozoa.

Table 5. Expected and observed numbers of germ cells arising from a basic stock of two ' $\mathrm{A}$ ' spermatogonia in mature and regressed testes of laboratory voles

\begin{tabular}{lrrr}
\hline \multirow{2}{*}{ Cell type } & Expected & \multicolumn{2}{c}{ Observed } \\
\cline { 3 - 4 } & & Mature & Regressed \\
\hline 'B' spermatogonia & 24 & $21 \cdot 3$ & $10 \cdot 2$ \\
Primary spermatocytes & 48 & $42 \cdot 0$ & $20 \cdot 7$ \\
Round spermatids & 192 & $113 \cdot 8$ & $36 \cdot 4$ \\
Spermatozoa & 192 & $114 \cdot 5$ & $35 \cdot 6$ \\
\hline
\end{tabular}

\section{DISGUSSION}

The continuous process of spermatogenesis can, in the vole as in other mammals, be divided into a number of stages each comprising a characteristic association of germ cells. The eight stages recognized in this study corresponded in general terms to those described for the ram, rabbit, bull and stallion (Ortavant, 1958; Swierstra \& Foote, 1963; Hochereau-de Reviers, 1970; Swierstra, Gebauer \& Pickett, 1974). The prominent chromatin body in nuclei may correspond to the X and Y chromosomes (Matthey, 1950; Sachs, 1953). The frequencies of the stages (Table 2) reflect their durations, those of high frequency (such as stage VIII in the vole) representing long steps, and those of low frequency (stage III in the vole), short steps in spermatogenesis. There was no difference between the laboratory stock of voles and wild-type animals in the frequency of the eight stages, although the laboratory colony had been a closed one for 12 to 13 years, and other differences in reproductive biology from wild voles developed during this period (J. R. Clarke, unpublished observations). There are differences between species, however, in the frequency of some stages. Thus, the most frequent in the vole is stage VIII $(22.9 \%$ laboratory, $24.1 \%$ field animals) but, in the rabbit, ram, bull and stallion it is stage $\mathrm{I}(27.7 \%, 21.7 \%$, $30.8 \%$ and $16.9 \%$, respectively). The least frequent in the vole and stallion is stage III $(5 \cdot 1$ to $5.2 \%, 3.2 \%)$ and in the rabbit, ram and bull it is stage V $(4 \cdot 1 \%, 4.2 \%$ and $1.6 \%$, respectively) (Courot, Hochereau-de Reviers \& Ortavant, 1970; Swierstra, Gebauer \& Pickett, 1974). It is unlikely that these differences between species are due to differences in the precision of recognition of the stages, since, for example, stage I differs in its cellular composition from stage VIII strikingly and in the same way in the vole, rabbit, bull and stallion. 
There appear to be real differences between species in the duration of particular stages as well as in the whole of the seminiferous epithelial cycle (Courot et al., 1970).

It is clear from a consideration of cell numbers in both mature and regressed testes that there are two periods in spermatogenesis when germ cells are lost on a large scale, namely during spermatogonial mitotic and spermatocytic meiotic divisions. It is not certain to what extent the slight loss of spermatozoa in stages VII and VIII of mature testes is due to mortality or to passage down tubules. The losses during the divisions of spermatogonia and spermatocytes are very much larger in regressed than in mature testes. Similar effects have been observed in the ram (Ortavant, 1958). Since testes from voles kept in short photoperiods, or trapped in the field in winter, are very often much more regressed than those studied here, cell losses frequently must be even greater. The seasonal changes in spermatogenesis in the vole and other species appear to be due to alterations in the number of cells surviving rather than to changes in the rate of spermatogenesis, which has been regarded as constant for any one species (Ortavant et al., 1969). Testis and seminal vesicle weights (Table 1) suggest that circulating levels of gonadotrophins and testicular hormones were lower in the voles with regressed testes than in the sexually mature animals. It may be that these hormones, known to influence spermatogenesis in other species (Ortavant \& Courot, 1967; Steinberger \& Duckett, 1967; Courot, 1971), control the wastage of germ cells. Previous results (Clarke \& Kennedy, 1967; Grocock \& Clarke, 1974) and the present ones have shown that a few spermatozoa are produced by some voles living in short photoperiods. This presumably reflects the release of small amounts of gonadotrophins or testicular hormones in animals which, for some reason, are less susceptible than others to the effects of short photoperiods.

Table 6. Numbers of spermatogonia at each stage of spermatogenesis in sexually mature laboratory voles

\begin{tabular}{lccccccccc}
\hline & \multicolumn{1}{c}{ Cell type } & \multicolumn{1}{c}{ Stage of spermatogenesis } \\
\cline { 2 - 9 } & $I$ & $I I$ & $I I I$ & $I V$ & $V$ & $V I$ & $V I I$ & $V I I I$ \\
\hline 'A' spermatogonia & 4 & 4 & 5 & $5^{*}$ & 4 & $3^{*}$ & 2 & $2^{*}$ \\
Intermediate spermatogonia & & & & 1 & $4^{*}$ & $8^{*}$ & $7^{*}$ & 1 \\
'B' spermatogonia & & & & & & 1 & 12 & 21 \\
\hline
\end{tabular}

Values are numbers of spermatogonia per tubule cross-section.

* Cross divisions occur here.

The assessment of the numbers of the different sorts of germ cell allows some suggestion to be made about how the spermatogonia divide to produce the progressively more highly differentiated germ cells while at the same time perpetuating stem cells. The figures for spermatogonia in Table 3 have been altered to whole numbers (Table 6) and, from these, the scheme of cell divisions shown in Text-fig. 1 has been developed. It should be emphasized that any such scheme has separated a continuous process of divisions into apparently distinct, precisely synchronized, steps. Three different generations of ' $\mathrm{A}$ ' spermatogonia 
$\left(A_{1}, A_{2}\right.$ and $\left.A_{3}\right)$ have been postulated. They have not yet been recognized as different cell types in the vole, although several sorts of ' $A$ ' spermatogonia have been recognized in the rat and bull (Clermont \& Bustos-Obregon, 1968; Hochereau-de Reviers, 1970). It is also supposed that there are two different lines of cells, lineage 1 and lineage 2, differing in the timing and products of division. The separation into stem cells and others which go on to become spermatozoa is considered to take place between stages VIII and I. Three of the four ' $\mathrm{A}_{2}$ ' spermatogonia ultimately give rise to primary spermatocytes and spermatozoa. The fourth is regarded as in some way different so that its division yields ' $\mathrm{A}_{1}$ ' spermatogonia. The details of the further divisions in lineage 1 and lineage 2 are as follows. At the end of stage IV, all ' $\mathrm{A}_{2}$ ' spermatogonia divide, those in lineage 1 giving rise to four intermediate spermatogonia in stage $\mathrm{V}$.

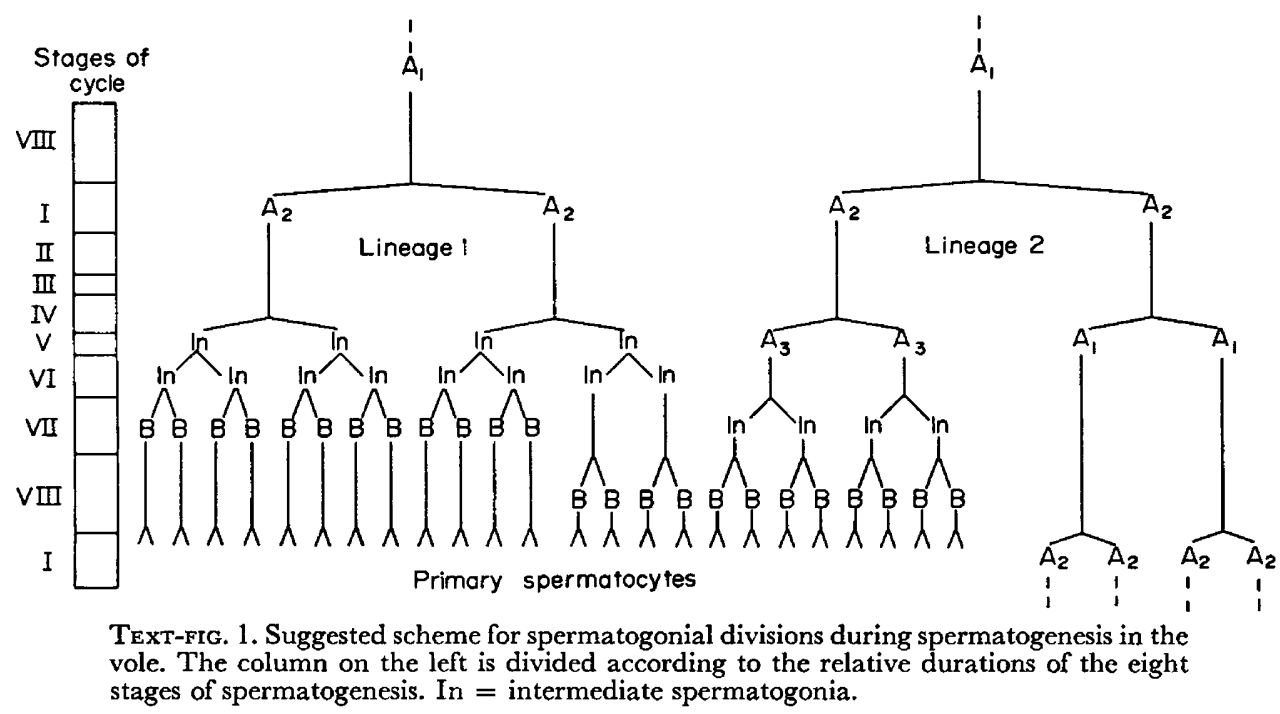

These in their turn divide to form eight intermediate spermatogonia in stage VI. Subsequent division of these during stages VII and VIII yields sixteen ' $B$ ' spermatogonia by stage VIII. In lineage 2, division of ' $A_{2}$ ' spermatogonia yields ' $\mathrm{A}_{3}$ ' and ' $\mathrm{A}_{1}$ ' spermatogonia. The ' $\mathrm{A}_{3}$ ' produce four intermediate spermatogonia by stage VII and eight ' $\mathrm{B}$ ' spermatogonia by stage VIII. Divisions in the two cell lines will thus provide a total of twenty-four ' $B$ ' spermatogonia by stage VIII.

Like the schemes of cell division drawn up for other species (see Clermont, 1972) the present one suggested for the vole has some special features of division and differentiation which should be emphasized. Essentially, this is the general developmental problem of how mitotic divisions yield unequal products. Lineages 1 and 2 begin with cells of the same designation (' $\mathrm{A}_{1}$ ' spermatogonia), but while one line produces only ' $B$ ' spermatogonia, the other by unequal division yields not only ' $B$ ' but the original type of ' $A_{1}$ ' spermatogonia. Alternative schemes of cell division could be devised which would be consistent with the observed numbers of cells but, in any event, the same problems of division and differentiation would be posed, as they have in schemes for other species. 
Methods are required by which the validity of such schemes could be tested. As far as the vole is concerned, the recognition of morphologically different ' $\mathrm{A}$ ' and intermediate spermatogonia would increase the authenticity of the scheme. Likewise, if the nuclei of ' $\mathrm{A}_{1}$ ' spermatogonia were to be labelled with $\left[{ }^{3} \mathrm{H}\right]$ thymidine, then the labelling of nuclei should be reduced to $\frac{1}{2}, \frac{1}{4}, \frac{1}{8}$ in subsequent generations of cells. Such changes have been shown to occur in the bull (Hochereau-de Reviers, 1970). It is conceivable too that by separation of germ cells (Bruce, Lam, Hughes \& Furrer, 1970; Lam, Furrer \& Bruce, 1970) and their cultivation in vitro (Steinberger \& Steinberger, 1965, 1967) with or without reimplantation into intact animals, it would be possible to demonstrate the existence of cell groups differing in their developmental fates and the timing of divisions.

\section{AGKNOWLEDGMENTS}

We are indebted to Professor G. E. Blackman and Professor J. H. Burnett for providing the facilities for this work, and to Miss Judith Tompkins for invaluable technical assistance. One of us (C.A.G.) was the recipient of a Ministry of Agriculture, Fisheries and Food Post-graduate Studentship.

\section{REFERENCES}

Baker, J. R. \& Ranson, R. M. (1932) Factors affecting the breeding of the field mouse (Microtus agrestis). Part 1. Light. Proc. R. Soc. B, 110, 313-322.

Baker, J. R. \& Ranson, R. M. (1933) Factors affecting the breeding of the field mouse (Microtus agrestis). Part 3. Locality. Proc. $R$. Soc. B, 113, 486-495.

Bruce, W. R., Lam, D. M. K., Hughes, T. J. \& Furrer, R. (1970) Physical and chemical studies of sperm production. Can. med. Ass. 7. 103, 885-888.

Chitty, D. \& Kempson, D. A. (1949) Prebaiting small mammals and a new design of live trap. Ecology, $30,536-542$.

Crarke, J. R. \& Forsyth, I. A. (1964) Seasonal changes in the gonads and accessory reproductive organs of the vole (Microtus agrestis). Gen. $\mathcal{E}$ compar. Endocr. 4, 233-242.

Clarke, J. R. \& Kennedy, J. P. (1967) Effect of light and temperature upon gonad activity in the vole (Microtus agrestis). Gen. E् compar. Endocr. 8, 474-488.

Clermont, Y. (1972) Kinetics of spermatogenesis in mammals: seminiferous epithelium cycle and spermatogonial renewal. Physiol. Rev. 52, 198-236.

Clempont, Y. \& Bustos-Obregon, E. (1968) Re-examination of spermatogonial renewal in the rat by means of seminiferous tubules mounted 'in toto'. Am. F. Anat. 122, 237-247.

Courot, M. (1971) Etablissement de la spermatogénèse chez l'agneau (Ovis aries):étude expérimentale de son contrôle gonadotrope; importance des cellules de la lignée sertolienne. Thèse, docteur ès science, Université de Paris, pp. 1-200.

Gourot, M., Hochereau-de Reviers, M. T. \& Ortavant, R. (1970) Spermatogenesis. In The Testis, Vol. I, pp. 339-432. Eds. A. D. Johnson, W. R. Gomes and N. L. VanDemark. Academic Press, New York and London.

Grocock, C. A. \& ClaRke, J. R. (1974) Photoperiodic control of testis activity in the vole, Microtus agrestis. F. Reprod. Fert. 39, 337-347.

Hochereau-De Reviers, M. T. (1970) Etudes des divisions spermatogoniales et du renouvellement de la spermatogonie souche chez le taureau. Thèse, docteur ès sciences, Université de Paris, pp. 1-134.

LAM, D. M. K., Furrer, R. \& BRUCE, W. R. (1970) The separation, physical characterization and differentiation kinetics of spermatogonial cells of the mouse. Proc. natn. Acad. Sci. U.S.A. 65, 192199.

Matthey, R. (1950) Les chromosomes sexuels géants de Microtus agrestis L. Cellule, 53, 163-184.

Ortavant, R. (1958) Le cycle spermatogénétique chez le bélier. Thèse, docteur ès sciences, Université de Paris, pp. 1-127. 
Ortavant, R. \& Courot, M. (1967) Action des hormones gonadotropes sur la lignée germinale male adulte. Archs Anat. microsc. Morph. exp. 56, Suppl. 3-4, 111-124.

Ortavant, R., Courot, M. \& Hochrreau, M. T. (1969) Spermatogenesis and morphology of the spermatozoon. In Reproduction in Domestic Animals, 2nd edn, pp. 251-276. Eds. H. H. Cole and P. T. Cupps. Academic Press, New York and London.

Roosen-Runge, E. C. \& Gieser., L. O. (1950) Quantitative studies on spermatogenesis in the albino rat. Am. 7. Anat. 87, 1-30.

SACHs, L. (1953) The giant sex chromosomes in the mammal Microtus agrestis. Heredity, Lond. 7, 227-238.

Steingerger, A. \& Steinberger, E. (1965) Differentiation of rat seminiferous epithelium in organ culture. 7. Reprod. Fert. 9, 243-248.

Steinberger, A. \& Steinberger, E. (1967) Factors affecting spermatogenesis in organ cultures of mammalian testes. F. Reprod. Fert., Suppl. 2, 117-124.

Steinberger, E. \& Duckett, G. E. (1967) Hormonal control of spermatogenesis. F. Reprod. Fert., Suppl. 2, 75-87.

Swierstra, E. E. \& Foote, R. H. (1963) Cytology and kinetics of spermatogenesis in the rabbit. F. Reprod. Fert. 5, 309-322.

Swierstra, E. E., Gebauer, M. R. \& Pickett, B. W. (1974) Reproductive physiology of the stallion. I. Spermatogenesis and testis composition. J. Reprod. Fert. 40, 113-123. 